\title{
EXCEL VBA ALKALMAZÁSA EGY BIOMETRIAI ESETTANULMÁNY PÉLDÁJÁN BEMUTATVA
}

\author{
Hampel György
}

\begin{abstract}
Absztrakt: Az Excel táblázatkezelö program olyan szolgáltatásait alkalmazhatjuk hatékonyan, melyekkel nagymennyiségü adat egy-egy részével ismétlődően kell végrehajtani statisztikai kiértékeléseket. Szerepük alapján külön munkalapon kerültek elhelyezésre a kiértékelendő adatok, a statisztikai számítási eljárások és az eredményeket összesítő táblázatok. A munkalapok közötti adatmozgást az éppen szükséges adatok kiválasztásával Visual Basic for Application program látja el. Egy termény két termesztési módjának összehasonlítására mért 44 kémiai összetevő mennyiségének kiértékelése során csaknem félezerszer végrehajtott statisztikai számítás eredményét kapjuk meg összesítve, táblázatba rendezett formában az elkészített VBA programmal.

Abstract: Excel spreadsheet programs can be used efficiently to perform statistical evaluations repeatedly with a large amount of data. Based on their role, the data to be evaluated, the statistical calculation procedures and the tables summarizing the results were placed on separate worksheets. The data transfer between the worksheets and the selection of the required data is performed by Visual Basic for Application. The prepared VBA program creates the result of almost half a thousand statistical calculations in a cumulative, tabular form to evaluate the measured amount of 44 chemical components in order to compare two crop cultivation methods.
\end{abstract}

Kulcsszavak: Excel, VBA, statisztikai kiértékelés

Keywords: Excel, VBA, statistical evaluation

\section{Bevezetés}

A táblázatkezelő programokat jellemzően adatok feldolgozására, különböző számítási műveletek elvégzésére alkalmazzuk. A korai verzióikhoz képest funkcióik jelentösen kibövültek, s ezeket sokszor nem is ismerjük, valamint csak csekély hányadát alkalmazzuk mindennapi munkánk során. Pedig sokszor jelentősen segítené munkánkat, ha ismernénk és tudnánk alkalmazni őket. Ebben az esettanulmányban bemutatásra kerül, hogy az Excel Visual Basic for Application funkciója segítségével minimális, pár óra alatt elsajátítható programozói ismeret birtokában milyen nagy fegyver lehet a kezünkben az egyébként monoton ismétlődő számítási feladatok gyors elvégzésére.

\section{Anyag és módszer}

A statisztikai módszerekkel kiértékelendő adatok egy termény, mintánként 44 kémiai összetevőjének méréséböl adódtak. A minták a termény három fajtájából, három egymást követő évben, két termesztési mód szerint álltak rendelkezésre. Azonos feltételek, mint fajta, év és termesztési mód esetében három párhuzamos mérés történt. Tehát $44 \times 3 \times 3 \times 2 \times 3=2376$ numerikus adatot kell statisztikai módszerekkel kiértékelni.

\subsection{Az Excel és a VBA}

A kiértékeléshez az Excel táblázatkezelő program biztosított minden szükséges hátteret (Bártfai, 2016): 
- Az adatok strukturált tárolása.

- A kiértékeléshez szükséges számítási támogatás.

- A kiértékelendő minták adatainak szürése.

- Programozási környezet (VBA: Visual Basic for Application) az ismétlődő számítási eljárások automatizálásához (Walkenbach, 2013).

\subsection{A Mann-Whitney-próba}

A statisztikai kiértékelés során a két termesztési mód során adódó adatokat kellett összehasonlítani. Ezt a párhuzamos mérések háromelemű mintáin kellett elvégezni. A Mann-Whitney-próba ilyen kevés elemszámú minták esetén is alkalmazható (Vargha, 2002), ráadásul a kétmintás t-próbával szemben a normális eloszlás sem követelmény (Fidy-Makara, 2005; Sándor-Ádány, 2011). Az adatok egységes kiértékelésének céljából a Mann-Whitney-próbát alkalmaztuk.

\section{Eredmények és értékelésük}

$\mathrm{Az}$ adatok jól kiértékeléséhez több részfeladat megoldására volt szükség:

- Excel munkalap kialakítása az adatok olyan strukturált tárolása, mely biztosította az algoritmizálható kiértékelhetöséget.

- A Mann-Whitney-próba számításait elvégző munkalap elkészítése.

- VBA program készítése a beállított feltételeknek megfelelő adatok kiszürésére és áthelyezésére a számításikat elvégző lapra.

- VBA program készítése, mely generálja a szürési feltételeket és táblázatba rendezetten helyezi el az egyes szürésekkel kapott statisztikai eredményeket.

\subsection{Az adatok elrendezése munkalapon}

$\mathrm{Az}$ adatok algoritmizálható visszakereshetőségét, szürését kellett biztosítani az adatok megfelelő elrendezésével. Azaz, ha egy-egy sorszám jellegü adat jelzi a szürendő adatsor esetén:

- a termény termesztési évét ( 1,2 vagy 3$)$,

- a termény fajtáját $(1,2$ vagy 3$)$,

- a kémiai összetevőt $(1,2, \ldots, 44)$, akkor VBA programmal kiszámítható legyen, hogy a kétfajta termesztési mód esetén ismert három-három darab adat hol található a táblázatban. Az adatok megfelelő elrendezését az 1. táblázat mutatja. 


\section{1. táblázat: Az adatok elrendezése}

\begin{tabular}{|c|c|c|c|c|c|c|c|}
\hline Év & Fajta & 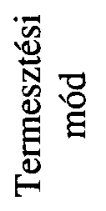 & 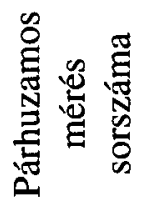 & 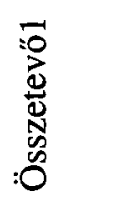 & 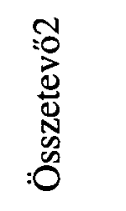 & $\vdots$ & 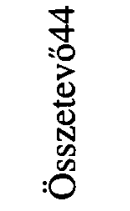 \\
\hline 2014 & fajta 1 & mód1 & 1 & 3,230 & 4,575 & $\ldots$ & 16,992 \\
\hline 2014 & fajtal & mód1 & 2 & 2,869 & 6,561 & $\ldots$ & 16,614 \\
\hline 2014 & fajta 1 & módl & 3 & 2,632 & 7,931 & $\ldots$ & 19,182 \\
\hline 2014 & fajtal & mód2 & 1 & 5,749 & 9,183 & $\ldots$ & 16,614 \\
\hline 2014 & fajtal & mód2 & 2 & 5,874 & 9,851 & $\ldots$ & 15,557 \\
\hline 2014 & fajtal & mód2 & 3 & 5,076 & 9,517 & $\ldots$ & 16,086 \\
\hline 2014 & fajta 2 & módl & 1 & 5,537 & 8,849 & $\ldots$ & 10,799 \\
\hline 2014 & fajta2 & mód1 & 2 & 7,034 & 8,849 & $\ldots$ & 11,403 \\
\hline 2014 & fajta2 & mód1 & 3 & 5,500 & 9,266 & $\ldots$ & 12,008 \\
\hline 2014 & fajta2 & mód2 & 1 & 2,295 & 10,602 & $\ldots$ & 19,333 \\
\hline 2014 & fajta2 & mód2 & 2 & 1,571 & 10,602 & $\ldots$ & 18,125 \\
\hline 2014 & fajta2 & mód2 & 3 & 1,609 & 10,518 & $\ldots$ & 18,200 \\
\hline$\ldots$ & & & $\cdots$ & .. & & . & .. \\
\hline 2016 & fajta3 & mód1 & 1 & 5,924 & 11,019 & $\ldots$ & 19,408 \\
\hline 2016 & fajta3 & mód1 & 2 & 4,328 & 8,598 & $\ldots$ & 12,234 \\
\hline 2016 & fajta3 & mód1 & 3 & 5,076 & 10,685 & $\ldots$ & 15,783 \\
\hline 2016 & fajta3 & mód2 & 1 & 2,819 & 10,685 & $\ldots$ & 23,260 \\
\hline 2016 & fajta3 & mód2 & 2 & 2,856 & 10,936 & $\ldots$ & 21,447 \\
\hline 2016 & fajta3 & mód2 & 3 & 3,642 & 12,271 & $\ldots$ & 22,505 \\
\hline
\end{tabular}

Forrás: A szerzỏ saját szerkesztése.

Hat sort igényel, hogy egy adott év és fajta esetén a két termesztési mód 3-3 párhuzamos méréséből származó 44 féle kémiai összetevő értékét tároljuk. Így 54 sorban soronként 44 adat található, azaz 2376 adat.

3.2. A Mann-Whitney-próba számításainak munkalapja

A statisztikai kiértékelés lapját úgy kellett kialakítani, biztosítsa:

- a szürési feltételek beállíthatóságát,

- a szürés végrehajtását,

- a szürt adatok tárolását, megjelenítését,

- a szürt adatoktól függő statisztikai számítás végrehajtását,

- a statisztikai számítás eredményének tárolását, megjelenítését.

A szürési feltételek (év, fajta, mód) beállítását három cella biztosítja. Ezek a cellák felhasználóbarát módon legördülö listában jelenítik meg a választható lehetöségeket.

Amikor beállítottuk a feltételeket, egy parancsgombra klikkelve indíthatjuk el azt a VBA programot, mely az adatokat tartalmazó munkalapról kigyüjti a 
számítások munkalapjára a feltételeknek megfelelő adatokat. Az így megváltozott adatok miatt újraértékelődnek a számítások munkalap további cellái, azaz megkapjuk a statisztikai kiértékelés eredményét egy cellában.

A kialakított munkalap univerzális módon bármely két adatsor összehasonlítására alkalmas a Mann-Whitney-próba alapján, tehát bármikor alkalmazható, újrahasznosítható.

\subsubsection{A szürés VBA programja}

A szürést elvégző, adatok() nevủ szubrutin utasításait láthatjuk a következő sorokban (1. program).

Public sub adatok()

\section{1. program: A szürést elvégző adatok 0 szubrutin}

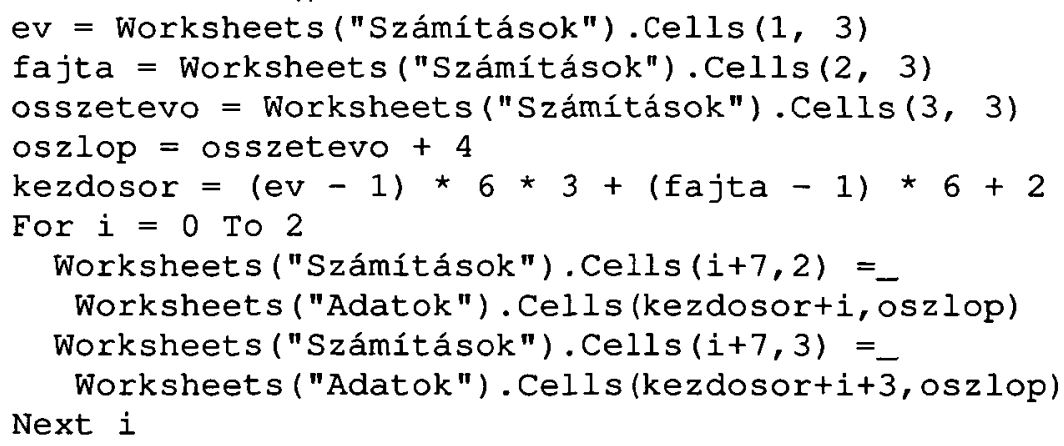

Forrás: A szerző saját szerkesztése.

Az első három utasítás beállítja az ev, fajta és oss zetevo változók értékét a Számítások munkalap egyes celláiból kiolvasott értékekre. A következő utasítások kiszámítják a szürendő adatok elhelyezkedését, s ez lesz az os z lop és a kezdosor változók értéke. Az adatok kiolvasását az Adatok munkalapról, és elhelyezésüket a $S$ zámítások lapra egy For . . . Next ciklus végzi el. A ciklus biztosítja, hogy az utasítások ciklikusan többször végrehajtódjanak. Erre azért van szuikség, mert a kétféle termesztési mód 3-3 adatát kell kiolvasni egymást követő sorokból.

\subsection{A számítások automatizálása}

Kihasználhatjuk, hogy a „Számítások” munkalapon újraértékelődik az eredmény amikor megváltoznak rajta az adatok. Így lehetőségünk van egy VBA szubrutinnal (2. program), hogy generálva egymás után a szükséges szüréseket, az ehhez tartozó eredményeket egy táblázatba gyüjtsük össze. A táblázatban évenként, fajtánként és összetevőnként megkapjuk a kétféle termesztési mód összehasonlításának eredményeit. Mindez 3 év, 3 fajta és 44 összetevő esetén 3×3×44=396 ismétlése a Mann-Whitney-próbának. Az eredményeket a program egy 44 sorból és 9 oszlopból álló táblázatban helyezi el. 


\subsubsection{A számítássorozatot generáló VBA program}

Az elözö szubrutinhoz (1. program) képest az eltérés, hogy ez a szubrutin (2. program) az ev, fajta és osszetevo változók értékét nem kiolvassa egy munkalapról, hanem egy-egy For ciklusban állítja be, hogy milyen kezdőérték és végérték között változzanak. Így nem csak egy adott értékük mellett értékelödik ki a Mann-Whitney-próba, hanem a változók minden értékvariációja mellett. Ezért kellett úgy kialakítani a ciklusokat, hogy egymásba ágyazottak legyenek. Ez azt jelenti, hogy a külső ciklus változójában beállított egyes érték mellett a belső ciklus változójának minden egyes értéke esetén végrehajtódnak az utasítások. Így a számítások minden termesztési év, fajta és kémiai összetevő esetén végrehajtódnak. Természetesen minden kiértékelést követően az eredmény a Számítások munkalapról átkerül az Eredmények munkalap táblázatába. Azaz automatikusan elkészül az eredményeket összesítő táblázat a VBA program segítségével.

\section{2. program: A számítások automatizálását elvégző szamitas() szubrutin} Public Sub szamitas()

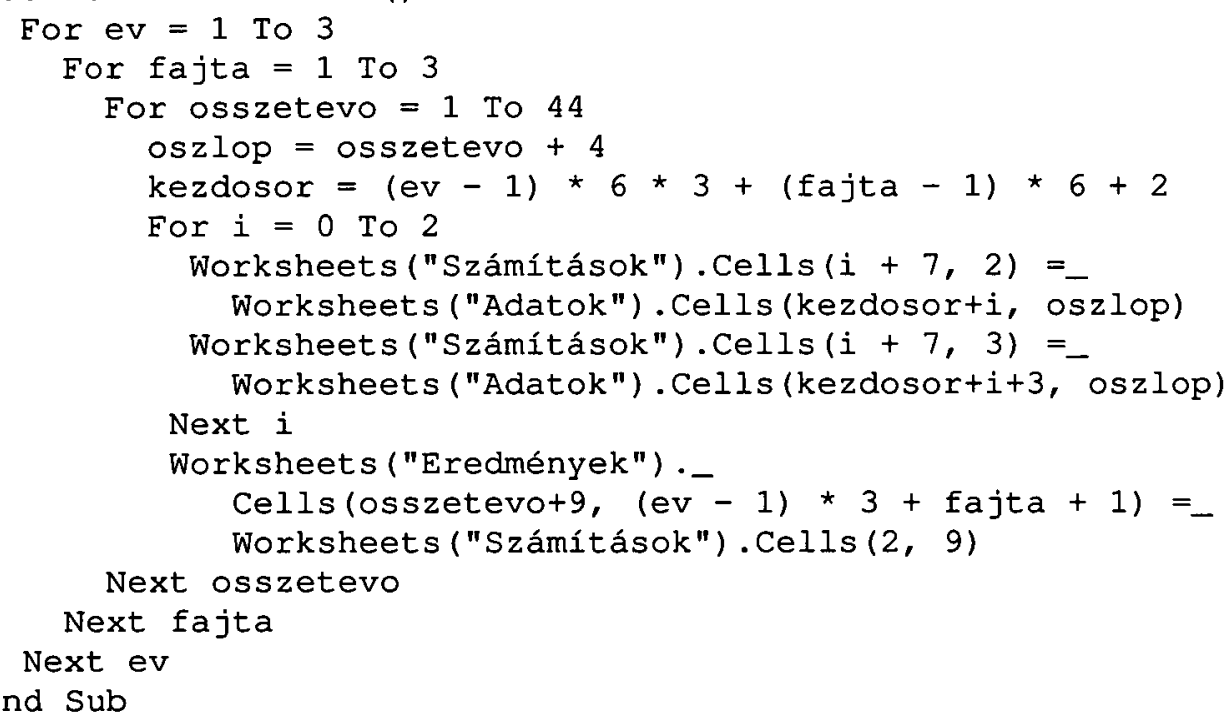

Forrás: A szerző saját szerkesztése.

\section{Következtetések, összegzés, záró megjegyzések, záró gondolatok}

$\mathrm{Az}$ Excel táblázatkezelö nagy lehetőséget biztosít számunkra munkánk automatizálásához a Visual Basic for Application fejlesztőeszközeinek segítségével. Ezt ismétlődő számítási feladatok esetén tudjuk hatékonyan kihasználni.

\section{Irodalomjegyzék}

Bártfai B. (2016): Office 2016 - Word, Excel, Access, Outlook, PowerPoint. BBS-Info Könyvkiadó, Budapest.

Fidy J., Makara G. (2005): Biostatisztika. InforMed 2002 Kft., Budapest.

Sándor J., Ádány R. (2011): Biostatisztika. Medicina Könyvkiadó, Budapest. 
Vargha A. (2002): Független minták összehasonlítása új rangsorolási eljárásokkal. Statisztikai Szemle, 80 (4): 354-370.

Walkenbach, J. (2013): Excel VBA Programming for Dummies. 3rd edition. John Wiley \& Sons Inc., New Jersey. 